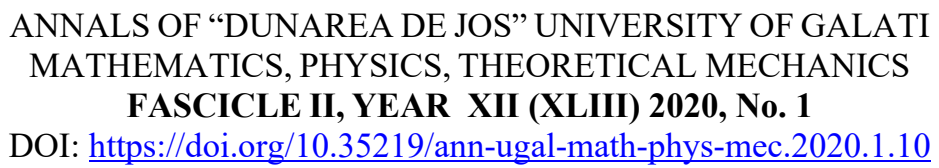

\title{
Assessment of nutrients and oxygen regime in the Lower Danube water
}

\author{
Madalina Calmuc ${ }^{1,}$, Valentina Andreea Calmuc ${ }^{1}$, \\ Lucian P. Georgescu ${ }^{1}$, Catalina Iticescu ${ }^{1}$, Maxim Arseni ${ }^{1 *}$ \\ 1 “Dunarea de Jos" University of Galati, European Center of Excellence for the Environment, Faculty of \\ Sciences and Environment, 111 Domneasca Street, 800201, Galati, Romania \\ *Corresponding author: maxim.arseni@ugal.ro
}

\begin{abstract}
The oxygen regime and nutrients are among the quality indicators covered by the Water Framework Directive 2000/60/EC (WFD) that must be monitored in order to establish the ecological status of the surface water. The WFD defines, for each indicator, five quality classes that are transposed in Romania by Ministerial Order (M.O.) 161/2006. The main aim of this study is to assess the oxygen and nutrient regime of the Lower Danube water according to M.O. 161/2006. 35 water samples were collected monthly from 7 sampling stations situated near the cities of Braila and Galati during the period of March-July 2019. Three oxygen regime indicators i.e. Dissolved Oxygen (DO), Biochemical Oxygen Demand ( $\mathrm{BOD}_{5}$ ), Chemical Oxygen Demand (COD), and five nutrients i.e. Nitrate nitrogen $\left(\mathrm{N}_{-} \mathrm{NO}_{3}^{-}\right)$, Nitrite-nitrogen $\left(\mathrm{N}^{-} \mathrm{NO}_{2}{ }^{-}\right)$, Ammonium-nitrogen $\left(\mathrm{N}^{-} \mathrm{NH}_{4}{ }^{+}\right)$, Total nitrogen $(\mathrm{TN})$ and Ortho-phosphates $\left(\mathrm{P}_{-} \mathrm{PO}_{4}{ }^{3-}\right)$ were analyzed in this study. The results showed that $\mathrm{DO}$ and $\mathrm{BOD}_{5}$ were parameters which recorded significant temporal variations (spring-summer) in all 7 sampling station. DO levels varied from values specific for the quality Class I in spring to values specific for the quality Class III during the summer, while $\mathrm{BOD}_{5}$ values varied from Class I to Classes II-IV. Following the evaluation of the nutrient values, the Danube water quality was classified in Classes I, II, or III. Nutrient concentrations corresponding to a lower quality were recorded near the confluence areas of the Danube with the Siret and the Prut Rivers (S3 and S6 sampling stations).
\end{abstract}

Keywords: oxygen regime, nutrients, temporal variation, quality classes

\section{INTRODUCTION}

The Water Framework Directive (WFD) was adopted by the European Parliament and the Council of the European Union with a view of establishing a common framework for the protection of inland surface waters, groundwater, transitional and coastal waters. Its main objective is to achieve a good ecological status (second quality class) in all surface water by 2015 [1]. In accordance with WFD, biological, hydromorphological, chemical, and physicochemical indicators are the qualitative elements of a river that must be monitored in order to establish its ecological status. The general chemical and physicochemical indicators required by WFD are thermal conditions, oxygen regime, salinity, acidification level, and nutrient concentrations. For each indicator, the following five quality classes with threshold values specific for each country are defined: Class I (high), Class II (good), Class III (moderate), Class IV (poor), and Class V (bad) [2-4]. These limit values are transposed in the Romanian legislation by Ministerial Order (M.O.) 161/2006 approving the Norms on surface water quality classification to determine the ecological status of water bodies [5].

The purpose of this study is to assess the nutrient concentrations and oxygen regime of the Lower Danube water (Braila-Galati area) in accordance with the requirements of the M.O. 161/2006. Furthermore, the correlations between the analysed indicators were studied.

Assessment of nutrient concentrations in surface waters is important because excessive intakes of phosphorus $(\mathrm{P})$ and nitrogen $(\mathrm{N})$ are the main cause of eutrophication, which impairs the 
biodiversity, structure, and functions of the aquatic ecosystem [6-7]. The main anthropogenic sources of nutrients within the Danube Basin are the agricultural sector, households, and industry [8-9]. The indicators that describe the oxygen conditions of the surface waters are dissolved oxygen (DO), biochemical oxygen demand $\left(\mathrm{BOD}_{5}\right)$, and chemical oxygen demand $(\mathrm{COD}) . \mathrm{BOD}_{5}$ and $\mathrm{COD}$ parameters are often monitored to establish the level of organic matter in water [10]. Urban wastewater untreated or improperly treated before discharge, agriculture (mainly the animal breeding sector), and industry (especially the pulp and paper, textile, chemical, and food industry) are the main sources of organic pollution of Danube water [11]. Monitoring the level of dissolved oxygen in water bodies is essential because it plays a vital role for in the aquatic biota, a low level even causing the death of organisms $[12,13]$.

\section{EXPERIMENTAL}

The water samples were collected monthly from seven sampling stations on the Danube River, located on the sector near the cities of Galati and Braila during the period of March-July 2019. To evaluate the water quality in this sector, seven reference sampling stations were located from the middle of the watercourse from upstream to downstream. The map with the geographic distribution of the sampling sites is represented in Figure 1.
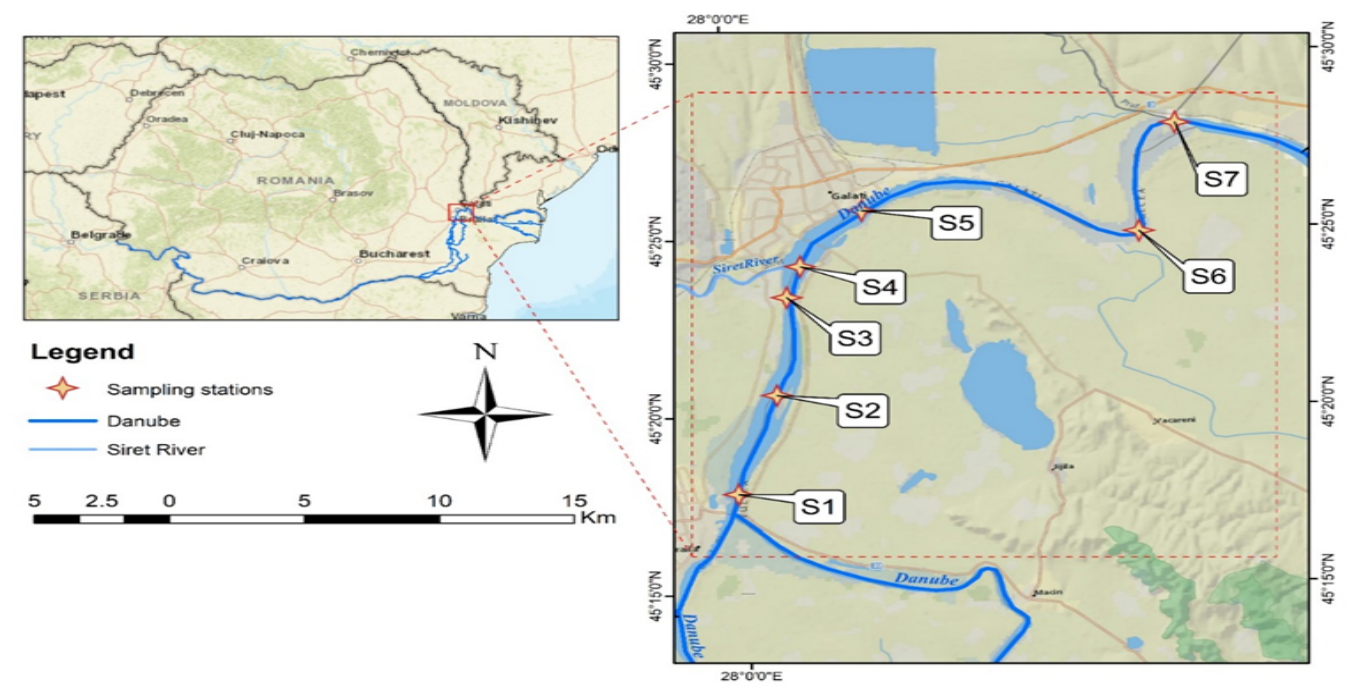

Fig. 1. The map of sampling stations

After sampling, the water samples were transported to the CREDENTIAL laboratory within the "Dunarea de Jos" University of Galati, where they were analysed in the shortest time possible. The physicochemical indicators determined experimentally for this study are the nutrients i.e. Nitrate nitrogen $\left(\mathrm{N}_{-} \mathrm{NO}_{3}{ }^{-}\right)$, Nitrite-nitrogen $\left(\mathrm{N}^{-} \mathrm{NO}_{2}{ }^{-}\right)$, Ammonium-nitrogen $\left(\mathrm{N}-\mathrm{NH}_{4}{ }^{+}\right)$, Total nitrogen $(\mathrm{TN})$, Ortho-phosphates (P-PO ${ }_{4}^{3-}$ ), and the oxygen regime i.e. Dissolved Oxygen (DO), Biochemical Oxygen Demand in five days $\left(\mathrm{BOD}_{5}\right)$, Chemical Oxygen Demand (COD). Figures 2 (a, b, c, d) illustrate the instruments that were used to analyze the water samples:

(a) NOVA 60 A Spectrophotometer used to determine $\mathrm{COD}, \mathrm{N}-\mathrm{NO}_{3}{ }^{-}, \mathrm{N}-\mathrm{NO}_{2}{ }^{-}, \mathrm{N}^{-} \mathrm{NH}_{4}{ }^{+}, \mathrm{TN}, \mathrm{P}^{-} \mathrm{PO}_{4}{ }^{3-}$ concentrations.

(b) Thermoreactor TR 60 necessary for the digestion of water samples;

(c) Multiparameter analyser HANNA HI9828 used to determine the values of Dissolved Oxygen in situ;

(d) BOD System used to quantify the Biochemical Oxygen Demand in five days. 


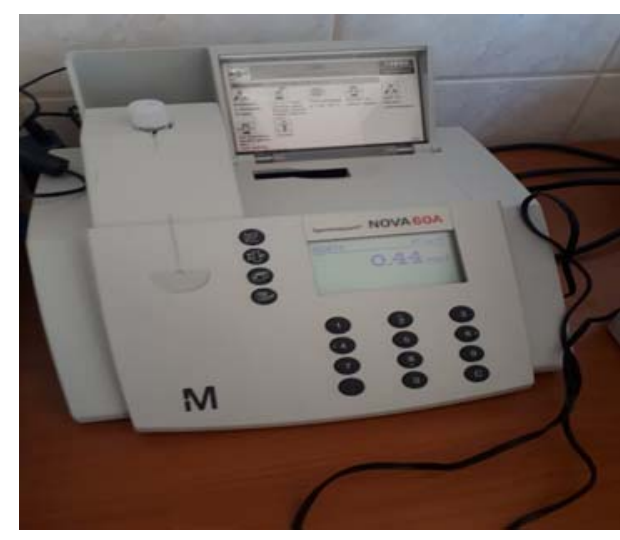

(a)

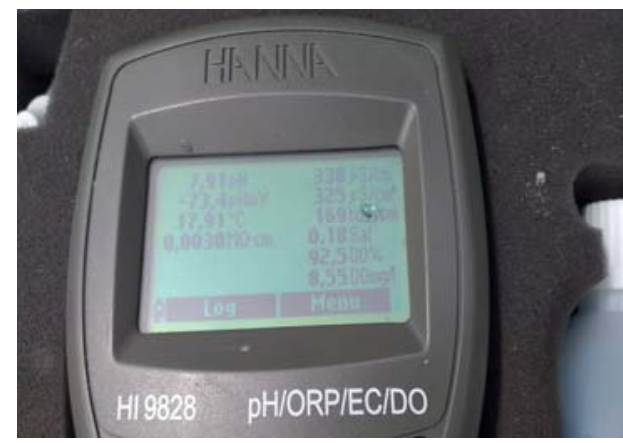

(c)

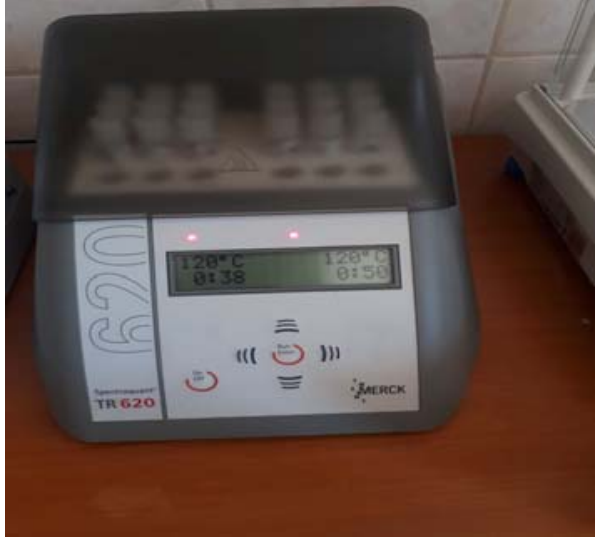

(b)

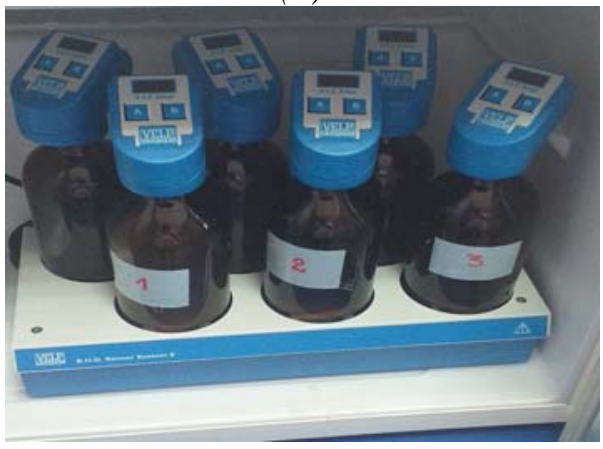

(d)

Fig. 2 Instruments used for water sample analysis

(a) NOVA 60A spectrophotometer (b) Thermoreactor TR60 (c) HI9828 HANNA Multiparameter (d) BOD System

\section{RESULTS AND DISCUSSION}

In order to assess the temporal and seasonal variation of nutrients and oxygen regime levels in accordance with M.O. 161/2006, the experimental results were represented graphically in Figures 2 and 3. The limit values of the monitored indicators for the 5 quality classes regulated by the Order 161/2006 are summarized in Table 1.

Table 1. The limit values corresponding to the 5 quality classes regulated by M.O. 161/2006 [5]

\begin{tabular}{|c|c|c|c|c|c|c|}
\hline \multirow[t]{2}{*}{ Indicator } & \multirow[t]{2}{*}{ Unit } & \multicolumn{5}{|c|}{ The limit values for the 5 quality classes } \\
\hline & & $\mathrm{I}$ & II & III & IV & $\mathrm{V}$ \\
\hline DO & $\left(\mathrm{mg} \mathrm{O}_{2} / \mathrm{L}\right)$ & 9 & 7 & 5 & 4 & $<4$ \\
\hline BOD & $\left(\mathrm{mg} \mathrm{O}_{2} / \mathrm{L}\right)$ & 3 & 5 & 7 & 20 & $>20$ \\
\hline COD & $\left(\mathrm{mg} \mathrm{O}_{2} / \mathrm{L}\right)$ & 10 & 25 & 50 & 125 & $>125$ \\
\hline $\mathrm{N}^{-\mathrm{NH}_{4}}{ }^{+}$ & $(\mathrm{mg} \mathrm{N} / \mathrm{L})$ & 0,4 & 0.8 & 1.2 & 3.2 & $>3.2$ \\
\hline TN & $(\mathrm{mg} \mathrm{N} / \mathrm{L})$ & 1.5 & 7 & 12 & 16 & $>16$ \\
\hline $\mathrm{N}^{-\mathrm{NO}_{3}}{ }^{+}$ & $(\mathrm{mg} \mathrm{N} / \mathrm{L})$ & 1 & 3 & 5.6 & 11.2 & $>11.2$ \\
\hline $\mathrm{N}^{-\mathrm{NO}_{2}}{ }^{+}$ & $(\mathrm{mg} \mathrm{N} / \mathrm{L})$ & 0.01 & 0.03 & 0.06 & 0.3 & $>0.3$ \\
\hline $\mathrm{P}-\mathrm{PO}_{4}^{3+}$ & $(\mathrm{mg} \mathrm{P} / \mathrm{L})$ & 0.1 & 0.2 & 0.4 & 0.9 & $>0.9$ \\
\hline
\end{tabular}


Nutrient concentrations in the investigated water samples are represented in Fig. 3 (a, b, c, d). From the results presented in Fig. 3 (a, b, c, d), there can be observed that values of nutrients corresponding to quality classes I, II, and III were obtained throughout the monitoring period. Analyzing the spatial variation of these results, it is seen that the highest values of $\mathrm{N}^{-\mathrm{NH}_{4}}{ }^{+}(3.2 \mathrm{mg}$ $\mathrm{N} / \mathrm{L}), \mathrm{P}_{-} \mathrm{PO}_{4}{ }^{3-}{ }^{-}(0.36 \mathrm{mg} \mathrm{P} / \mathrm{L}), \mathrm{N}_{-} \mathrm{NO}_{3}{ }^{-}(4.4 \mathrm{mg} \mathrm{N} / \mathrm{L})$, and $\mathrm{TN}(7.5 \mathrm{mg} \mathrm{N} / \mathrm{L})$ were recorded in $\mathrm{S} 4$ and S6 sampling stations. It is important to note that these stations are located at the confluence of the Danube with the Siret (S4) and Prut (S6) rivers. Thus, the results mentioned above highlight the contribution of the two tributaries on the quality of the Danube water, especially on the level of nutrients. This may be due to fertilizers applied to agricultural land in the vicinity of the two tributaries. In addition, this explanation can be supported by the fact that the highest concentrations of nutrients were recorded in the spring season when melted snow on adjacent land drains into watercourses [14].



(a)

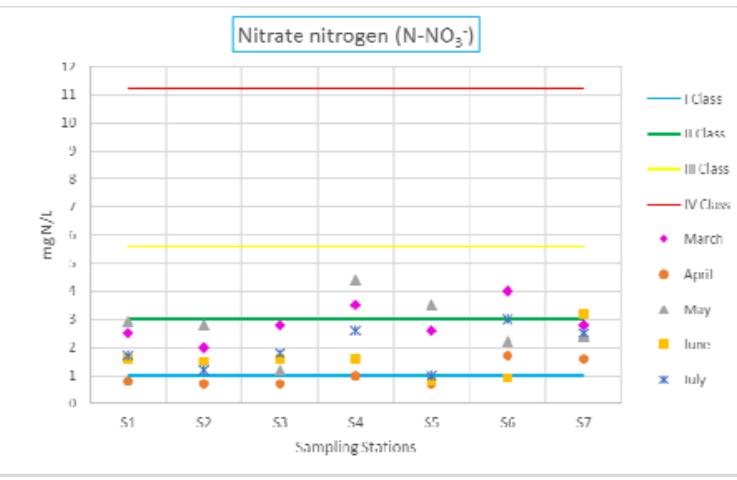

(c)

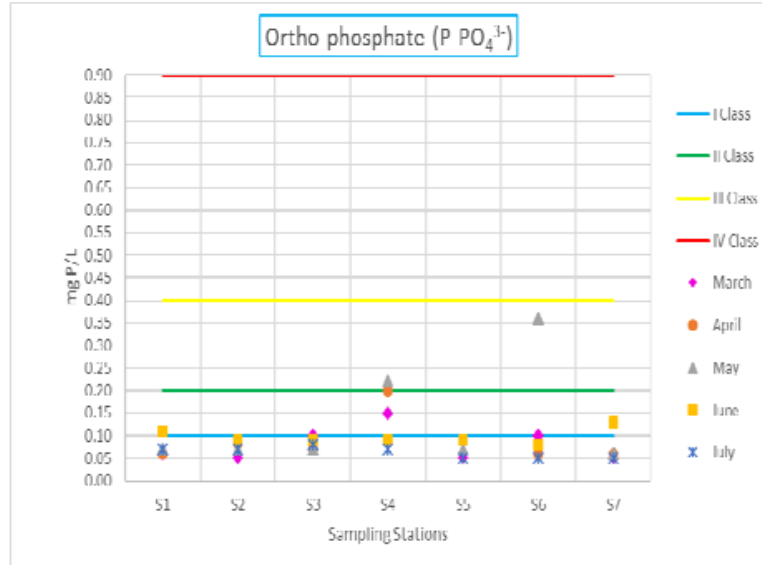

(b)

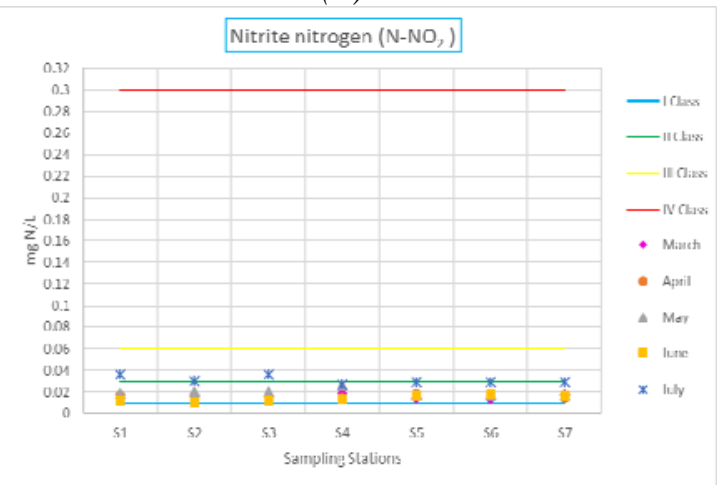

(d)

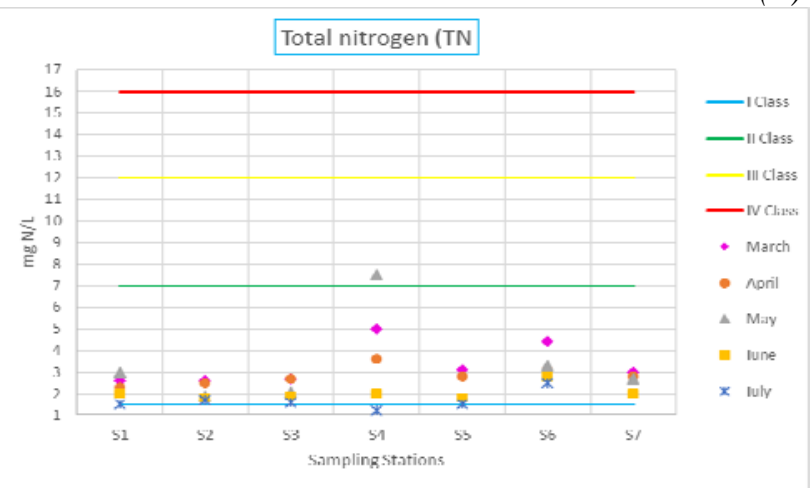

(e)

Fig. 3. Temporal and spatial variation of nutrient concentrations (a) $\mathrm{N}-\mathrm{NH}_{4}^{+}$(b) $\mathrm{P}_{-} \mathrm{PO}_{4}{ }^{3-}$ (c) $\mathrm{N}_{-} \mathrm{NO}_{3}{ }^{-}$ (d) $\mathrm{N}-\mathrm{NO}_{2}^{-}$(e) $\mathrm{TN}$ 
In terms of spatio-temporal variation of the indicators specific to the oxygen regime, from Fig. $4(\mathrm{a}, \mathrm{b}, \mathrm{c})$ it can be observed that the dissolved oxygen level registered the largest seasonal variation. An explanation for this result may be the dependence of dissolved oxygen on temperature, as higher temperatures favor the acceleration of biological activities and, consequently the decrease of dissolved oxygen level in water [15]. This is also represented in Fig. 4 (a) where there can be seen how the values of DO corresponding to quality class I (10.1-12.7 $\mathrm{mg} \mathrm{O}_{2} / \mathrm{L}$ ) were recorded in the spring season (especially in March and April), while values corresponding to classes II and III (5.6-8.8) in summer. Also, the Biochemical Oxygen Demand indicator, recorded values corresponding to a lower quality class (III-IV) during the summer, probably due to the opposite dependence between temperature and solubility of oxygen in water [16]. According to the results obtained following the experimental determination of the Chemical Oxygen Demand (COD), the water quality was classified in classes I, II, and rarely III (Fig. 4 c). An increased level of COD suggests that biologically resistant organic substances are present in the water [17].

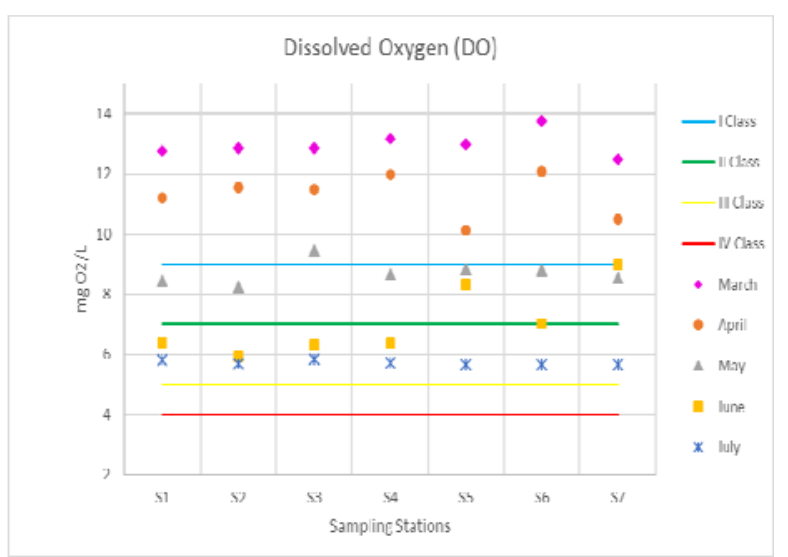

(a)

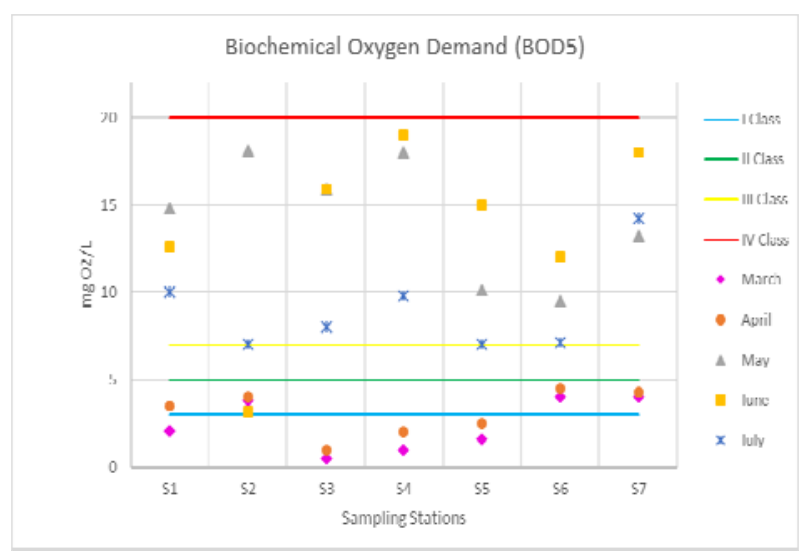

(b)



(c)

Fig. 4 Temporal and spatial variation of $\mathrm{DO}(\mathrm{a}), \mathrm{BOD}_{5}(\mathrm{~b})$ and $\mathrm{COD}(\mathrm{c})$ levels

In this study, the correlation relations between the analyzed physicochemical indicators were also studied. From the correlation matrix represented in Table 2, it can be observed a positive correlation between $\mathrm{N}-\mathrm{NH}_{4}{ }^{+}$and $\mathrm{N}-\mathrm{NO}_{2}{ }^{-}, \mathrm{TN}$, and $\mathrm{P}-\mathrm{PO}_{4}{ }^{3-}$ probably due to the presence of the same source of pollution, namely the agricultural activities carried out near the monitored area [4]. A negative correlation was obtained between DO and BOD suggesting that a high level of BOD and at the same time a low value of DO may be due to the organic matter present in the water [18-19]. 
Tab. 2 Correlation matrix for the analyzed indicators

\begin{tabular}{|c|c|c|c|c|c|c|c|c|}
\hline Variable & DO & BOD & COD & N-NH ${ }_{4}^{+}$ & TN & $\mathrm{N}-\mathrm{NO}_{3}{ }^{-}$ & $\mathrm{N}-\mathrm{NO}_{2}{ }^{-}$ & $\mathrm{P}_{-} \mathrm{PO}_{4}{ }^{3-}$ \\
\hline DO & 1.000000 & & & & & & & \\
\hline BOD & -0.598867 & 1.000000 & & & & & & \\
\hline COD & 0.297757 & -0.396327 & 1.000000 & & & & & \\
\hline${\mathrm{N}-\mathrm{NH}_{4}}^{+}$ & -0.202353 & 0.012713 & -0.121699 & 1.000000 & & & & \\
\hline TN & 0.487961 & -0.145298 & 0.192967 & 0.422696 & 1.000000 & & & \\
\hline $\mathrm{N}-\mathrm{NO}_{3}{ }^{-}$ & 0.167982 & 0.169092 & 0.179091 & 0.140944 & 0.394243 & 1.000000 & & \\
\hline $\mathrm{N}-\mathrm{NO}_{2}^{-}$ & -0.406283 & 0.137432 & 0.086350 & 0.480065 & -0.168627 & 0.095191 & 1.000000 & \\
\hline $\mathrm{P}^{-\mathrm{PO}_{4}{ }^{3-}}$ & 0.058779 & 0.106544 & -0.160823 & 0.193341 & 0.490268 & 0.182610 & -0.123692 & 1.000000 \\
\hline
\end{tabular}

\section{CONCLUSIONS}

In order to assess the nutrient and oxygen regime of the Lower Danube water in accordance with M.O.161/2006, eight physicochemical indicators were monthly analyzed during the period of March-July 2019. The monitored indicators recorded values corresponding to quality classes I-IV. $\mathrm{BOD}_{5}$ and $\mathrm{DO}$ parameters recorded significant temporal variations, perhaps due to the temperature differences from spring to summer. Regarding the nutrients values, high concentrations were obtained in the sampling stations located at the confluence of the Siret and Prut rivers with the Danube, especially in the spring season. These results highlight the contribution of the two tributaries on the level of nutrients in the Danube water. According to the correlation matrix, positive correlations between $\mathrm{N}-\mathrm{NH}_{4}{ }^{+}$and $\mathrm{N}-\mathrm{NO}_{2}{ }^{-}$, TN and $\mathrm{P}-\mathrm{PO}_{4}{ }^{3-}$, TN-DO were obtained, while between DO and BOD negative correlation was noticed.

\section{References}

1. Directive 2000/60/EC of the European Parliament and of the Council establishing a framework for the Community action in the field of water policy.

2. Cretescu .I, Kovács Z., Cimpeanu S.M., Monitoring of Surface Water Status in the Lower Danube Basin, in: River Basin Management, (Bucur D editor), Chapter 10, InTech, pp.206223, 2016.

3. Călmuc, M., Călmuc, V.A., Timofti, M., Iticescu, C., Georgescu, L.P., Ţopa, M.C., Review on water quality assessment in the Danube River Basin, Annals Dunarea De Jos Univ. Galati Fasc. II, 2 (2018), 189-195.

4. Radu V.M, Ionescu P., Deak G., Diacu E., Ivanov A.A., Zamfir S., Marcus M.I., Overall assessment of surface water quality in the Lower Danube River, Environ Monit Assess. 192(2) (2020) 135.

5. Order No. 161 of 16 February 2006 approving the Norms on surface water quality classification to determine the ecological status of water bodies.

6. Fregoso-López M.G., Armienta-Hernández M.A., Alarcón-Silvas S.G., Ramírez-Rochín J., Fierro-Sañudo J.F., Páez-Osuna F., Assessment of nutrient contamination in the waters of the El Fuerte River, southern Gulf of California, Mexico, Environ Monit Assess. 192(7) (2020) 417.

7. Zhang L., Shao S., Liu C., Xu T., Fan C., Forms of Nutrients in Rivers Flowing into Lake Chaohu: A Comparison between Urban and Rural Rivers, Water 7(12) (2015) 4523-4536. 
8. Lampert C. and Brunner P.H., Materials accounting as a policy tool for nutrient management in the Danube Basin, WGI ScI Tech. 40(10) (1999) 43-49.

9. Zessner M.,Gils J,. Nutrient fluxes from the Danube Basin to the Black Sea, Water Science and Technology 46(8) (2002) 9-17.

10. Tang X., Li R., Han D., Scholz M., Response of Eutrophication Development to Variations in Nutrients and Hydrological Regime: A Case Study in the Changjiang River (Yangtze) Basin, Water $12(6)$ ) (2020) 1634-1653.

11. http://www.danubesurvey.org/jds3/jds3-files/nodes/documents/factsheet3-jds3_0.pdf (accessed on 02.07.2020)

12. Sen Gupta, A., McNeil, B., Variability and Change in the Ocean, in: The Future of the World's Climate (Second Edition) (Henderson-Sellers, A., McGuffie, K., editors), Chapter 6, Elsevier, pp. 141-165, 2012.

13. Delorme, L.D., Ostracoda, in: Ecology and Classification of North American Freshwater Invertebrates (Second Edition) (Thorp, J. H. and Covich, A. P. editors), Chapter 20, Academic Press, pp. 811-848, 2001.

14. Iticescu, C., Murariu, G., Georgescu, L. P., Burada, A., Topa, C. M., Seasonal Variation of the Physico-chemical Parameters and Water Quality Index (WQI) of Danube Water in the Transborder Lower Danube Area, Rev. Chim .(Bucharest), 67(9) (2016) 1843-1949.

15. Fadaee, M., Mahdavi-Meymand, A., Zounemat-Kermani, M., Seasonal Short-Term Prediction of Dissolved Oxygen in Rivers via Nature-Inspired Algorithms. Clean - Soil, Air, Water 48 (1900300) (2020) 1-12.

16. Šiljić Tomić, A. N., Antanasijević, D. Z., Ristić, M. Đ., Perić-Grujić, A. A., Pocajt, V. V., Modeling the BOD of Danube River in Serbia using spatial, temporal, and input variables optimized artificial neural network models, Environ Monit Assess 188:300 (2016) 1-15.

17. Iticescu, C., Georgescu, L. P., Topa, C. \& Murariu, G. Monitoring the Danube Water Quality near the Galati City, Journal of Environmental Protection and Ecology 15(1) (2014) 30-38.

18. Susilowati, S., Sutrisno, J., Masykuri, M., Maridi, M. Dynamics and factors that affects DOBOD concentrations of Madiun River, AIP Conference Proceedings 2049, 020052 (2018), 115.

19. Călmuc M., Călmuc V.A., Iticescu C., Georgescu P.L, Timofti M., Arseni M., Țopa M.C., Roșu A.. Assessing the lower Danube water quality using the water pollution index. Tehnomus Journal (2019) 77-81.

Acknowledgments: Arseni Maxim's research work was supported by the project "ANTREPRENORDOC", Contract no. 36355/23.05.2019, financed by The Human Capital Operational Programme 2014-2020 (POCU), Romania and the work of Catalina Iticescu and Lucian P. Georgescu was supported by the Romanian Ministry of Research and Innovation, the project Excellence, performance and competitiveness in Innovation, Development, Research at "Dunarea de Jos" University of Galați, EXPERT. 